\title{
LOJALNOŚĆ KLIENTÓW INDYWIDUALNYCH WOBEC BANKU KOMERCYJNEGO
}

\author{
Piotr Grzegorz Pietrzak \\ Katedra Ekonomiki i Organizacji Przedsiębiorstw \\ Szkoła Główna Gospodarstwa Wiejskiego w Warszawie
}

\section{WALDEMAR JAROSŁAW POTOROCZYN}

\begin{abstract}
Abstrakt. Niestabilność otoczenia, w którym funkcjonują banki komercyjne oraz głębokie przeobrażenia zachodzące wewnątrz nich sprawiają, że przewartościowaniu ulegają zasady ich działania. Z instytucji chronionych wieloma przywilejami, banki komercyjne stały się podmiotami muszącymi sprostać presji nasilającej się konkurencji. Tym samym, temat lojalności klientów nabiera coraz większego znaczenia w strategiach marketingowych banków komercyjnych. Celem niniejszego artykułu uczyniono określenie stopnia lojalności klientów banku na przykładzie wybranego oddziału wareckiego banku komercyjnego „X””. W badaniach wykorzystano standardowy i „wzmocniony” wskaźnik lojalności. Analiza statystyczna obejmowała nieparametryczny test chi kwadrat $\left(\chi^{2}\right)$.
\end{abstract}

Słowa kluczowe: bankowość, marketing relacyjny, klient, lojalność.

\section{WSTĘP}

Procesy transformacji ustrojowej doprowadziły do głębokich przeobrażeń we wszystkich gałęziach polskiej gospodarki. Przemiany te nie ominęły również rynków finansowych. Reforma bankowa wprowadzona w 1989 r. stworzyła podstawy funkcjonowania konkurencyjnego sektora bankowego [Stodulny 2009, s. 5]. Pojawiły się nowe podmioty na rynku usług finansowych takie jak: pośrednicy 
kredytowi, towarzystwa leasingowe, fundusze inwestycyjne, czy SKOK-i [Stodulny 2009, s. 5]. Banki z pozycji instytucji zaufania publicznego przekształciły sie w przedsiębiorstwa działające na globalnym rynku, nastawione na maksymalizację zysku i generowanie wartości dla akcjonariuszy [Pawłowska 2005, s. 7].

Przemiany, które dokonały się w funkcjonowaniu banków diametralnie zmieniły ich dotychczasowe relacje $\mathrm{z}$ klientami. $\mathrm{W}$ warunkach nasilającej się konkurencji, klienta zaczęto postrzegać jako ten zasób banku, który kreuje wzrost jego wartości [Capiga 2004, s. 22]. Tym samym, coraz większą popularność w strategiach marketingowych banków zaczęło zdobywać podejście relacyjne, w literaturze anglojęzycznej określane mianem relationship banking [Boot 2000, s. 7-25]. Jak piszą Dibb i Meadows, celem banków przestało być przeprowadzenie jednorazowych transakcji, lecz nawiązywanie długich, intensywnych, a przede wszystkim rentownych więzi z klientami [2001, s. 173-174]. Realizacja tego celu wymusza na bankach konieczność podejmowania działań ukierunkowanych na budowanie lojalności, która traktowana jest jako kluczowa determinanta kapitału klientów [Caputa 2012, s. 545].

Celem niniejszego artykułu jest określenie stopnia lojalności klientów indywidualnych banku na przykładzie wybranego oddziału wareckiego banku komercyjnego „X"1. W ramach badań założono weryfikację następujących hipotez badawczych:

H1: Klienci indywidualni oddziału wareckiego banku komercyjnego „X" charakteryzują się niskim stopniem lojalności.

H2: Występuje statystycznie istotna zależność między wiekiem klientów indywidualnych oddziału wareckiego banku komercyjnego „X”, a stopniem ich lojalności.

\section{PRZEGLĄD LITERATURY}

Obecnie jednym ze źródeł przewagi konkurencyjnej jest odpowiednia obsługa i relacje z klientem [Drapińska 2009, s. 39]. Marketing relacyjny, wyrósł na bazie krytyki marketingu tradycyjnego - traktującego klienta jako biernego uczestnika procesu wymiany, którego zachowanie można kształtować przy użyciu odpowiednio dobranych instrumentów, takich jak: promocja, system dystrybucji, polityka produktowa, czy cenowa (4P) [Stodulny 2009, s. 46]. Storbacka i Lehtinen stwierdzają wręcz, że tradycyjny marketing, doprowadził do zerwania bezpośrednich kontaktów między producentem a klientem [2001, s. 18]. Stąd marketing relacyjny $\mathrm{w}$ przeciwieństwie do tradycyjnego stawia klienta jako partnera w proce-

\footnotetext{
${ }^{1}$ Dyrektor oddziału wareckiego banku komercyjnego „X” nie wyraził zgody na ujawnienie nazwy instytucji.
} 
sie wymiany, koncentruje się na tworzeniu długotrwałych związków [Pizło 2008, s. 90]. Dyskusję nad zmieniającą się rolą marketingu, trafnie podsumowuje Webster, którego zdaniem w marketingu relacyjnym punkt ciężkości przesuwa się z firmy do klientów, z transakcji do relacji, z produkcji do wspólnego kreowania wartości z partnerami biznesowymi i klientami [2005, s. 125].

Na bazie marketingu relacyjnego w odniesieniu do działalności bankowej wykształcił się termin relationship banking. W tej koncepcji podstawowy akcent kładzie się na korzyści wynikające z relacyjnego podejścia do działalności kredytowej [Zalega 2004, s. 95]. Relationship banking oznacza „stałe, wzajemne angażowanie się stron (banku i klienta) w budowanie długoterminowych relacji opartych na finansowaniu" [Zalega 2004, s. 95]. Podstawowym założeniem tej koncepcji jest uzyskiwanie przez bank wymiernych korzyści, które wynikają z kształtowania i utrzymywania związku z klientami. Relationship banking zakłada potrzebę podejmowania działań ukierunkowanych na budowanie lojalności klientów.

Lojalność jest zjawiskiem złożonym, polimorficznym, uwarunkowanym zarówno przyczynami zewnętrznymi i wewnętrznymi [Wojnarowska 2009, s. 93]. Ponadto lojalność zmienia się w czasie, ewoluuje pod wpływem różnych czynników [Wojnarowska 2009, s. 93]. Stąd bierze się trudność nie tylko w jej wyczerpującym opisie i analizie, ale również w jej poprawnym zdefiniowaniu.

W literaturze przedmiotu przedstawia się dwa podstawowe rozumienia lojalności [Siemieniako 2007, s. 67]. Po pierwsze - lojalność jako zachowanie klienta, tzw. lojalność behawioralna, i po drugie - lojalność jako postawa klienta tzw. lojalność afektywna [Siemieniako 2007, s. 67].

W podejściu opartym na wymiarze behawioralnym przyjmuje się, że nabywca, który systematycznie dokonuje zakupów w danym przedsiębiorstwie jest klientem lojalnym, bowiem „lojalność konsumenta oznacza dokonywanie zakupów produktów tej samej marki, zakupów w tym samym miejscu sprzedaży lub od tego samego sprzedawcy" [Rudawska 2011, s. 41]. W obecnych warunkach rynkowych traktowanie lojalności klienta jedynie jako powtarzanie zakupów jest zbyt powierzchowne. Uwzględnienie postaw nabywców w rozumieniu ich lojalności „staje się coraz bardziej popularnym podejściem zarówno teoretyków jak i praktyków marketingu" [Siemieniako 2007, s. 67]. Przyjmuje się powszechnie, że znajomość postawy daje możliwość przewidzenia reakcji jej posiadacza względem obiektu postawy w przyszłości [Stach 2008, s. 192]. Lojalność jako postawa powinna spełniać sześć warunków, co oznacza, że musi być ona (1) nieprzypadkową, (2) reakcją behawioralną, (3) ujawnioną w przestrzeni czasu, (4) przez określoną jednostkę, (5) w stosunku do jednej bądź kilku marek wybranych z większego zbioru marek substytucyjnych, (6) jako funkcja psychologicznych procesów podejmowania decyzji i oceny [Stach 2008, s. 192].

W odniesieniu do rynku usług bankowych lojalność klientów można definiować jako „określony stan stosunku klienta do banku świadczącego mu usługi, 
oparty na trwałości, długoterminowości oraz akceptacji oferowanych warunków świadczenia poszczególnych usług" [Smyczek 2000, s. 6]. Lojalnego klienta banku cechuje: dokonywanie regularnych, powtarzających się zakupów usług bankowych, rozpowszechnianie pozytywnych informacji o banku wśród innych osób, wysoka odporność na ofertę oraz działania promocyjne banków konkurencyjnych, chęć powtórnych zakupów [Griffin 1997, s. 213].

Na lojalność klientów banków wypływa stopień zaspakajania określonych oczekiwań. Oczekiwania te dotyczą w szczególności: niezawodności (polegającej na rzetelnym spełnieniu obietnic, zgodności usług z ofertą banku), wrażliwości (związanej z dokładną i kompleksową obsługą przez personel), wyglądu (nie tylko placówek bankowych ale i ich pracowników), dostępności, kompetencji, uprzejmości oraz przejrzystości (pracownicy banku powinni komunikować się z klientami w sposób zrozumiały) [Opolski 1998, s. 102].

Najogólniej lojalność klientów banków można zróżnicować na podzielną (klient korzysta z usług/produktów dwóch lub większej liczby instytucji finansowych w sposób równoległy lub naprzemienny) i niepodzielną (klient korzysta wyłącznie z usług/produktów oferowanych przez jeden bank) [Matysik-Pejas 2007, s. 135].

Znajomość stopnia ${ }^{2}$ lojalności klientów banku posiada kluczowy wpływ na wybór odpowiedniej strategii marketingowej - określa wykorzystywane instrumenty, ich znaczenie, czas i częstotliwość stosowania [Grzegorczyk 2001, s. 25].

\section{METODY BADAŃ}

Niniejsze badanie ma charakter pilotażowy, dlatego dokonano doboru celowego obiektu badawczego - oddziału wareckiego banku komercyjnego „X”. Zasadniczym źródłem danych do analiz były informacje pierwotne pochodzące z badań własnych. Badanie przeprowadzono metodą sondażu diagnostycznego z wykorzystaniem techniki kwestionariusza ankiety na grupie 35 respondentów (klienci indywidualni), którzy w okresie maj-czerwiec 2017 r. posiadali rachunek oszczędnościowo-rozliczeniowy w analizowanym oddziale i którzy wyrazili zgodę na wypełnienie ankiety (na zasadzie dobrowolności). W badaniu wzięło udział 19 kobiet i 16 mężczyzn (tabela 1).

Pozyskane dane pozwoliły na obliczanie dwóch wskaźników lojalności [Szafrańska, Kozioł 2010, s. 45]:

- $\quad$ standardowego

$$
L=\frac{D+R}{N}
$$

\footnotetext{
${ }^{2}$ Autorzy zakładają dwa stopnie lojalności: lojalność niepodzielną i podzielną.
} 
- „Wzmocnionego"

$$
L_{w}=\frac{D}{N}
$$

gdzie:

L - wskaźnik lojalności klientów (w \%),

D - liczba klientów deklarująca zdecydowaną chęć dalszego korzystania, z produktów/usług banku,

$\mathrm{R}$ - liczba klientów warunkowo deklarująca chęć dalszego korzystania z produktów/usług banku,

N - liczba klientów objętych badaniem,

$\mathrm{L}_{\mathrm{w}}-$ „Wzmocniony” wskaźnik lojalności klientów (w \%).

TABELA 1. Charakterystyka badanej próby

\begin{tabular}{|l|c|c|}
\hline \multicolumn{1}{|c|}{ Wyszczególnienie } & Liczba osób \\
\hline \multirow{4}{*}{ Wiek } & $18-25$ lat & 5 \\
\cline { 2 - 3 } & $26-35$ lat & 5 \\
\cline { 2 - 3 } & $36-45$ lat & 9 \\
\cline { 2 - 3 } & $46-55$ lat & 6 \\
\cline { 2 - 3 } & 56-65 lat & 7 \\
\hline \multirow{4}{*}{ Płeć } & powyżej 65 lat & 3 \\
\hline \multirow{4}{*}{ Wykształcenie } & kobieta & 19 \\
\cline { 2 - 3 } & mężczyzna & 16 \\
\hline \multirow{4}{*}{$\begin{array}{l}\text { Deklarowana sytuacja } \\
\text { finansowa }\end{array}$} & podstawowe & 4 \\
\cline { 2 - 3 } & zawodowe & 6 \\
\cline { 2 - 3 } & średnie & 13 \\
\cline { 2 - 3 } & wyższe & 2 \\
\cline { 2 - 3 } & bardzo dobra & 12 \\
\cline { 2 - 3 } & dobra & 7 \\
\cline { 2 - 3 } & przeciętna & 0 \\
\cline { 2 - 3 } & zła & 14 \\
\hline
\end{tabular}

Źródło: Opracowanie własne na podstawie danych z ankiet.

W celu określenia zależności pomiędzy lojalnością klientów indywidualnych, a ich wiekiem, płcią, wykształceniem oraz deklarowaną sytuacją finansową posłużono się testem niezależności chi kwadrat $\left(\chi^{2}\right)$. Testowanie hipotez zerowych nastąpiło przy poziomie istotności $\alpha=0,05$.

W procesie przetwarzania materiału badawczego wykorzystano arkusz kalkulacyjny Microsoft Excel 2013. 


\section{WYNIKI BADAŃ}

Jak zostało zauważone w przeglądzie literatury lojalność klientów banków można rozróżnić na podzielną i niepodzielną. Z przeprowadzonych badań wynika, że blisko ponad połowa respondentów (18 osób) korzystała tylko z produktów/usług banku komercyjnego „X” (klienci, których lojalność jest niepodzielna). Były to głównie kobiety w wieku 56-65 lat, z wykształceniem podstawowym, określające swoją pozycję finansową jako dobrą i bardzo dobrą. Pozostałe 17 osób współpracowało jednocześnie z Bankiem „X” i innymi instytucjami finansowymi (innymi bankami komercyjnymi, bankami spółdzielczymi czy instytucjami poza bankowymi).

Standardowy wskaźnik lojalności klientów indywidualnych kształtował się na poziomie 66\%, z kolei „wzmocniony” wskaźnik lojalności osiągnął wartość 37\%. Znacząca różnica pomiędzy standardowym a „wzmocnionym” wskaźnikiem lojalności może stanowić sygnał ostrzegawczy dla Banku „X”, ponieważ, w przypadku pojawienia się korzystnej alternatywy, część klientów skorzystałaby z konkurencyjnej oferty. Otrzymane wyniki badań są zbieżne z wynikami m.in. Smyczka, który wskazał, że dla banków komercyjnych standardowy wskaźnik lojalności wynosi 80\%, a najwyższa wartość współczynnika lojalności „wzmocnionej” kształtuje się na poziomie 43\% [2001, s. 83]. Ponadto warto nadmienić, że wskaźniki lojalności dla banków komercyjnych są zdecydowanie niższe od wartości współczynników otrzymanych dla sektora spółdzielczego [Szafrańska, Kozioł 2010, s. 51].

Wartości standardowego i „wzmocnionego” wskaźnika lojalności w przekroju poszczególnych cech (płeć, wiek, wykształcenie, deklarowana sytuacja finansowa) przedstawia tabela 2 .

Należy zauważyć, że zarówno w przypadku klientów w wieku od 18 do 25 lat, jak również w przypadku klientów posiadających wykształcenie zawodowe, „Wzmocniony” wskaźnik lojalności wyniósł 0. Oznacza to, że są to grupy klientów, które w przypadku otrzymania atrakcyjniejszej oferty od konkurencyjnych instytucji finansowych zrezygnowałyby z usług świadczonych przez Bank „X”.

W oparciu o otrzymane wyniki, można stwierdzić, że klienci indywidualni oddziału wareckiego Banku „X” charakteryzują się niskim poziomem lojalności. Tym samym hipoteza 1 została potwierdzona.

W kolejnym kroku analizy skonfrontowano stopień lojalności klientów indywidualnych (lojalność podzielna/niepodzielna) z ich płcią, wiekiem, wykształceniem i deklarowaną sytuacją finansową. Posłużono się testem niezależności chi kwadrat $\left(\chi^{2}\right)$. Analiza testem $\chi^{2}$ nie wykazała istotnej statystycznie zależności między płcią, wiekiem, poziomem wykształcenia, deklarowaną sytuacją finansową (tabele 3-6). Tym samym, hipoteza 2 głosząca, że występuje statystycznie istotna zależność między wiekiem klientów indywidualnych a stopniem ich lojalności została odrzucona. 
TABELA 2. Wskaźniki lojalności z uwzględnieniem płci, wieku, wykształcenia i deklarowanej sytuacji finansowej klientów

\begin{tabular}{|c|c|c|}
\hline Wyszczególnienie & $\begin{array}{c}\text { Standardowy wskaźnik } \\
\text { lojalności }\end{array}$ & $\begin{array}{c}\text { „Wzmocniony” wskaźnik } \\
\text { lojalności }\end{array}$ \\
\hline \multicolumn{3}{|c|}{ płeć } \\
\hline kobieta & $79 \%$ & $58 \%$ \\
\hline mężczyzna & $50 \%$ & $13 \%$ \\
\hline \multicolumn{3}{|c|}{ wiek } \\
\hline 18-25 lat & $60 \%$ & $0 \%$ \\
\hline 26-35 lat & $40 \%$ & $40 \%$ \\
\hline $36-45$ lat & $89 \%$ & $33 \%$ \\
\hline 46-55 lat & $50 \%$ & $33 \%$ \\
\hline 56-65 lat & $71 \%$ & $57 \%$ \\
\hline powyżej 65 lat & $67 \%$ & $67 \%$ \\
\hline \multicolumn{3}{|l|}{ wykształcenie } \\
\hline podstawowe & $67 \%$ & $67 \%$ \\
\hline zawodowe & $43 \%$ & $0 \%$ \\
\hline średnie & $77 \%$ & $46 \%$ \\
\hline wyższe & $58 \%$ & $42 \%$ \\
\hline \multicolumn{3}{|c|}{ deklarowana sytuacja finansowa } \\
\hline bardzo dobra & $50 \%$ & $50 \%$ \\
\hline dobra & $67 \%$ & $50 \%$ \\
\hline przeciętna & $71 \%$ & $29 \%$ \\
\hline zła & $57 \%$ & $29 \%$ \\
\hline
\end{tabular}

Źródło: Opracowanie własne na podstawie danych z ankiet.

TABELA 3. Tablica krzyżowa (lojalność/wiek)

\begin{tabular}{|l|c|c|c|c|c|c|c|}
\hline Zmienna & $18-25$ & $26-35$ & $36-45$ & $46-55$ & $56-65$ & $>65$ & razem \\
\hline lojalność niepodzielna & 3 & 2 & 4 & 2 & 5 & 2 & 18 \\
\hline lojalność podzielna & 2 & 3 & 5 & 4 & 2 & 1 & 17 \\
\hline razem & 5 & 5 & 9 & 6 & 7 & 3 & 35 \\
\hline
\end{tabular}

Źródło: Opracowanie własne.

TABELA 4. Tablica krzyżowa (lojalność/płeć)

\begin{tabular}{|l|c|c|c|}
\hline Zmienna & mężczyzna & kobieta & razem \\
\hline lojalność niepodzielna & 7 & 11 & 18 \\
\hline lojalność podzielna & 9 & 8 & 17 \\
\hline razem & 16 & 19 & 35 \\
\hline
\end{tabular}

Źródło: Opracowanie własne 
TABELA 5. Tablica krzyżowa (lojalność/wykształcenie)

\begin{tabular}{|l|c|c|c|c|c|}
\hline Zmienna & podstawowe & zawodowe & średnie & wyższe & razem \\
\hline lojalność niepodzielna & 3 & 2 & 6 & 7 & 18 \\
\hline lojalność podzielna & 1 & 4 & 7 & 5 & 17 \\
\hline razem & 4 & 6 & 13 & 12 & 35 \\
\hline
\end{tabular}

Źródło: Opracowanie własne.

TABELA 6. Tablica krzyżowa (lojalność/deklarowana sytuacja finansowa)

\begin{tabular}{|l|c|c|c|c|c|}
\hline Zmienna & bardzo dobra & dobra & przeciętna & zła & razem \\
\hline lojalność niepodzielna & 1 & 6 & 7 & 4 & 18 \\
\hline lojalność podzielna & 1 & 6 & 7 & 3 & 17 \\
\hline razem & 2 & 12 & 14 & 7 & 35 \\
\hline
\end{tabular}

Źródło: Opracowanie własne.

\section{WNIOSKI}

Obecne uwarunkowania rynkowe sprawiają, że lojalność klientów nie jest atutem banków, lecz coraz częściej decyduje o ich przetrwaniu. Problem lojalności nabiera kluczowego znaczenia zwłaszcza dla sektora banków komercyjnych, które poddawane są silnej presji konkurencyjnej, zarówno ze strony banków spółdzielczych, jak i ze strony instytucji parabankowych oferujących alternatywne źródła kredytowania i lokowania oszczędności.

Otrzymane w niniejszym artykule wyniki wskazują, że objęci badaniem klienci indywidualni oddziału wareckiego Banku „X” charakteryzują się niskim stopniem lojalności. Standardowy wskaźnik lojalności kształtował się na poziomie 66\%, z kolei „wzmocniony” wskaźnik lojalności osiągnął wartość jedynie 37\%. Ponadto analiza testem chi kwadrat $\left(\chi^{2}\right)$ nie wykazała istotnej statystycznie zależności pomiędzy lojalnością klientów a ich płcią, wiekiem, wykształceniem, czy deklarowaną sytuacją finansową. Tym samym hipoteza 1, głosząca, że klienci indywidualni oddziału wareckiego banku komercyjnego „X” charakteryzują się niskim stopniem lojalności została potwierdzana, zaś hipoteza 2 zakładająca, że występuje statystycznie istotna zależność między wiekiem klientów indywidualnych oddziału wareckiego banku komercyjnego „X”, a stopniem ich lojalności została odrzucona (przy poziomie istotności $\alpha=0,05$ ).

Oczywiście, należy pamiętać o ograniczeniach przeprowadzonych badań. Dotyczyły one wyłącznie jednego oddziału banku komercyjnego oraz obejmowały grupę wyłącznie 35 klientów indywidualnych. Dlatego otrzymane wyniki nie są reprezentatywne, a badania należy traktować, jako pilotażowe. Wskazana jest za- 
tem kontynuacja badań nad lojalnością klientów wobec banków komercyjnych. Warto w tym zakresie uwzględniać możliwie duże próby badawcze. Poza tym za interesujący kierunkiem badań autorzy uznają, rozpoznanie czynników determinujących postawy lojalnościowe klientów.

\section{Spis literatury}

B00T A.W. 2000: Relationship Banking. What Do we Know?, Journal of Financial Intermediation, 9, s. 7-25.

CAPIGA M. 2004: Kapitał klienta - przedmiot kompleksowej oceny działalności banku, Bank i Kredyt, 9, s. 22-30.

CAPUTA W. 2012: Lojalność klientów jako czynnik determinujący wartość kapitału klienta, Zeszyty Naukowe Uniwersytetu Szczecińskiego. Finanse, rynki finansowe, ubezpieczenia, 55, s. 529-556.

DIBB S., MEADOWS M. 2001: The Application of a Relationship Marketing Perspective in Retail Bank, The Service Industries Journal, 1, s. 169-194.

DRAPIŃSKA A. 2009: Marketing relacji - istota i czynniki wpływające na sukces, Zeszyty Naukowe Uniwersytetu Szczecińskiego. Ekonomiczne problemy usług, 41, s. 39-45.

GRIFFIN J. 1997: Customer Loyalty. How to Earn It, How to Keep It, Jossey-Bass Publishers, San Francisco.

GRZEGORCZYK W. 2001: Produkty bankowe - Rozwój i sprzedaż, Zarządzanie i Finanse, Warszawa.

MATYSIK-PEJAS R. 2007: Rola marki w procesie kształtowania lojalności nabywców produktów żywnościowych, Handel Wewnętrzny, 6, s. 135.

OPOLSKI K. 1998: Strategia jakości w nowoczesnym zarządzaniu bankiem, OLYMPUS Centrum Edukacji i Rozwoju Biznesu, Warszawa.

PAWŁOWSKA M. (red.) 2005: Konkurencja i efektywność na polskim rynku bankowym na tle zmian strukturalnych i technologicznych, Materiały i Studia - Narodowy Bank Polski.

PIZŁO W. 2008: Marketing relacji - koncepcja i kierunki rozwoju, Zeszyty Naukowe SGGW. Ekonomika i Organizacja Gospodarki Żywnościowej, 69, s. 89-98.

RUDAWSKA E. 2011: Lojalność klientów banków w obliczu nowych zasad walki o konta bankowe, (w:) S. Kaczmarczyk, J. Petrykowska (red.), Stan i rozwój marketingu w przedsiębiorstwach funkcjonujących na terenie Polski, Handel Wewnętrzny, 9-10, s. $40-47$.

SIEMIENIAKO D. 2007: Proces identyfikacji i kwalifikacji lojalnych klientów organizacji, (w:) S. Makarski (red.), Marketingowe mechanizmy kształtowania lojalności, Wydawnictwo Uniwersytetu Rzeszowskiego, Rzeszów, s. 67-73.

SMYCZEK S. 2000: Lojalność konsumentów a sukces rynkowy banku, Marketing i Rynek, 4, s. 6-12.

SMYCZEK S. 2001: Lojalność konsumenta na rynku. Wybrane zagadnienia, AE w Katowicach, Katowice. 
STACH P. 2008: Pomiar lojalności na rynku usług - empiryczna weryfikacja trafności wybranych symptomów lojalności, (w:) A. Nalepka (red.), Organizacje komercyjne i niekomercyjne wobec wzmożonej konkurencji oraz wzrastających wymagań konsumentów, Wydawnictwo Wyższej Szkoły Biznesu - National Louis University, Nowy Sącz, s. 190-201.

STORBACKA K., LEHTINEN J.R. 2001: Sztuka budowania trwałych związków z klientami, Oficyna Ekonomiczna, Kraków.

STODULNY P. 2009: Analiza satysfakcji i lojalności klientów banków, CeDeWu Sp. z o.o., Warszawa.

SZAFRAŃSKA M., KOZIOŁ A. 2010: Zachowania lojalnościowe klientów banków spółdzielczych, Zeszyty Naukowe Polityki Europejskie, Finanse i Marketing, 52, s. 45-56.

WEBSTER F.E. 2005: A Perspective on the Evolution of Marketing Management, Journal of Public Policy \& Marketing, 24, s. 121-126.

WOJNAROWSKA H. 2009: Rodzaje lojalności klientów i ich implikacje dla działań marketingowych przedsiębiorstwa, Zeszyty Naukowe Uniwersytetu Ekonomicznego w Krakowie, 823, s. 93-112.

ZALEGA K. 2004: Relationship banking jako struktura pośrednictwa finansowego, Bank i Kredyt, 6, s. 94-99.

\section{THE LOYALTY OF INDIVIDUAL CUSTOMERS OF COMMERCIAL BANK}

Abstract. The instability of commercial banks' environment and deep transformations which take place inside them are making redefinition of principles of their acting. From protected institutions with many privileges, commercial banks became entities which must meet the pressure of increasing competition not only from the cooperative banks, but also from other financial institutions and entities outside the banking sector. Thus, customer loyalty is becoming increasingly important in commercial bank marketing strategies. The purpose of this article was to determine the degree of loyalty of individual customers of branch of commercial bank " $X$ " in Warka. Loyalty indicator and enhanced loyalty indicator were used for the assessment of loyalty level. Statistical analysis comprised non parametric chi-square test $\left(\chi^{2}\right)$.

Key word: banking, relationship marketing, customer, loyalty. 